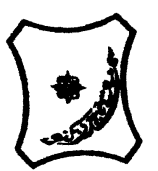

Bayero Journal of Pure and Applied Sciences, 10(2): 1 - 10

Received: October, 2017

Accepted: November, 2017

ISSN $2006-6996$

\title{
A SURVEY OF AVIFAUNA AND VEGETATION COMMUNITIES IN HADEJIA-NGURU WETLANDS, NIGERIA
}

\author{
Ringim, A. S. ${ }^{*}$ and Dogara, M. M. \\ Department of Biological Science, Federal University Dutse, P. M. B. 7156, Jigawa State, Nigeria \\ ${ }^{*}$ Correspondence: abubakar.r@fud.edu.ng
}

\begin{abstract}
An understanding of the ecological relationship between birds and vegetation is important for management and conservation of any wetland ecosystem. Despite the significant importance of the Hadejia-Nguru Ramsar site and an Important Bird Area, little is known about the ecological relationship between bird and vegetation communities. Bird diversity and density were examined and compared between Protected Areas (PAS) and Unprotected Areas (UPAs) with attention to vegetation diversity and density. Data were collected from October to December, 2015. A total of 14 wetland sites were surveyed (seven in PAs and seven in UPAs), and point count method was employed. In total, 42, 255 bird individuals, 148 species, 23 orders, and 50 families were identified. Two globally threatened species namely, European Turtle Dove (Streptopelia turtur) and Pallid harrier (Circus macrourus) were also recorded. Results showed that neither vegetation diversity nor density correlated with bird diversity nor density in both PAs and UPAs (p > 0.05), suggesting that there could be other factors that influence the bird diversity and density in both areas. PAs and UPAs of the Hadejia-Nguru Wetlands are rich in avifaunal species, thus management of these areas will preserve large species diversity. Increase public awareness in the wetland on the importance of conserving birds and vegetation, as they play a vital role in the ecosystem is strongly recommended. The results presented here provide an overview of the relationship between bird and vegetation communities of the Hadejia-Nguru Wetlands, an important input for better understanding of its conservation.
\end{abstract}

Key words: Bird diversity, Density, Hadejia- Nguru Wetlands, Protected and unprotected areas, Vegetation

\section{INTRODUCTION}

The Ramsar convention defined wetlands as "areas of marsh, fen, peat land or water, whether natural or artificial, permanent or temporary with water that is static or flowing, fresh, brackish or salt, including areas of marine water, the depth of which at low tide does not exceed six meters" (Barbier et al., 1997). Wetlands are distributed all over the world except Antarctica and represent about 4-6\% of the earth's surface (7-9 million $\mathrm{km}^{2}$ ), and ranked among the earth's most productive ecosystems (Mironga, 2006). Ecological values of wetlands to humans consists of flood control, nutrient absorption and cycling which improve water quality, as well as protection of coastal communities from erosion and wave energy (Barbier et al., 1997). Economic values of wetlands include agriculture, provision of timber, fuel wood, and non-timber products, such as cotton, silk and potash (Barbier et al., 1997). On the other hand, it has been shown that vegetation community is an essential component influencing bird species (Bideberi, 2013). This is due to the vegetation that serves as a great determinant for bird species diversity and density by providing foraging and nesting ground (Riffel et al., 2001) and cover from predation (Hurlbert, 2004).

Due to this, studies on the relationship between birds and vegetation have been conducted in various parts of the world including Australia (Neave et al., 2006), South America (Beese and Bryant, 1999), Asia (Hawkins et al., 2007) and Africa (Sulaiman et al., 2014). Some of them (e.g. Neave et al., 2006, Beese and Bryant, 1999) explained the relationship between plant species composition and bird diversity. A study by Kumar and Gupta (2009) found many birds to exploit a variety of wetland habitats likely due to high foraging ground and/or shelter for nesting and roosting. It has also been shown that different bird species select a variety of wetland habitats based on their choice and preferences (Bideberi, 2013). For instance, Cattle egret Bubulcus ibis that feed primarily on insects such as crickets, grasshoppers and ants prefer wetland areas with short grasses for foraging. In contrast, species like ducks, geese and waders which feed on invertebrates (e.g. molluscs, crustaceans, etc.) and fish prefer lakes and ponds (Bideberi, 2013).

In the Hadejia-Nguru Wetlands (HNWs), the wetlands consist of mosaic wetland areas including marshes, swamps, ponds, rivers and floodplains. The wetland comprises of four Protected Areas (PAs) as well as several wetland areas that have no legal protection which in this study are considered as Unprotected Areas (UPAs). 
Important studies on birds of the HNWs exist. Ezealor and Giles (1997) demonstrated that Ruff Philomachus pugnax are not pest of Rice Oryza spp., despite rice being its main constituent diet in the wetland. Lameed (2011) brought out to light the bird diversity and abundance of Dagona Waterfowl Sanctuary and the positive relationship between vegetation densities and bird diversity. Sulaiman et al. (2015) reported that wetland sizes do not have effect on bird abundance, but had effect on bird diversity. Nevertheless, our knowledge in understanding the relationship between birds and vegetation in the HNWs is inadequate. The aim of this paper is to provide an overview of the relationship between bird diversity/density versus vegetation diversity/density in PAs and UPAs of the HNWs.

\section{MATERIAL AND METHODS}

\section{Description of the study area}

The HNWs $\left(12^{\circ} 15^{\prime} \mathrm{N} 13^{\circ} 00 \mathrm{~N} ; 1^{\circ} 00^{\prime} \mathrm{E} 11^{\circ} 00^{\prime} \mathrm{E}\right.$, Figure 1 ) is form by the Hadejia and Jama'are rivers, to form the Yobe river, which drained into Lake Chad. The wetland cover about 3500000 ha situated on altitudinal range between 152-305 $\mathrm{m}$ a.s.l. Three main vegetation types are recognized, namely: (i) Scrub savannah which consists of upland farmland areas and Acacia woodlands, (ii) Raised areas locally known as tudu which become inundated during the wet season and predominated by tree species such as Acacia $s p p_{\text {, }}$ Ziziphus spp, and Desert date Balanites aegyptiaca, and (iii) Seasonally flooded areas of marsh with trees of Acacia spp and Doum palm Hyphaene thebaica, common grasses includes Egyptian crowfoot grass Dactyloctenium aegyptium and Giant sensitive tree Mimosa pigra along the Lakes (Birdlife International, 2016a). There are four PAs in the HNWs (Table 1). The wetland is a Ramsar site and an Important Bird Area, which has been recognized as one of the most important wintering site for migratory birds in the Sahel (Birdlife International, 2013).

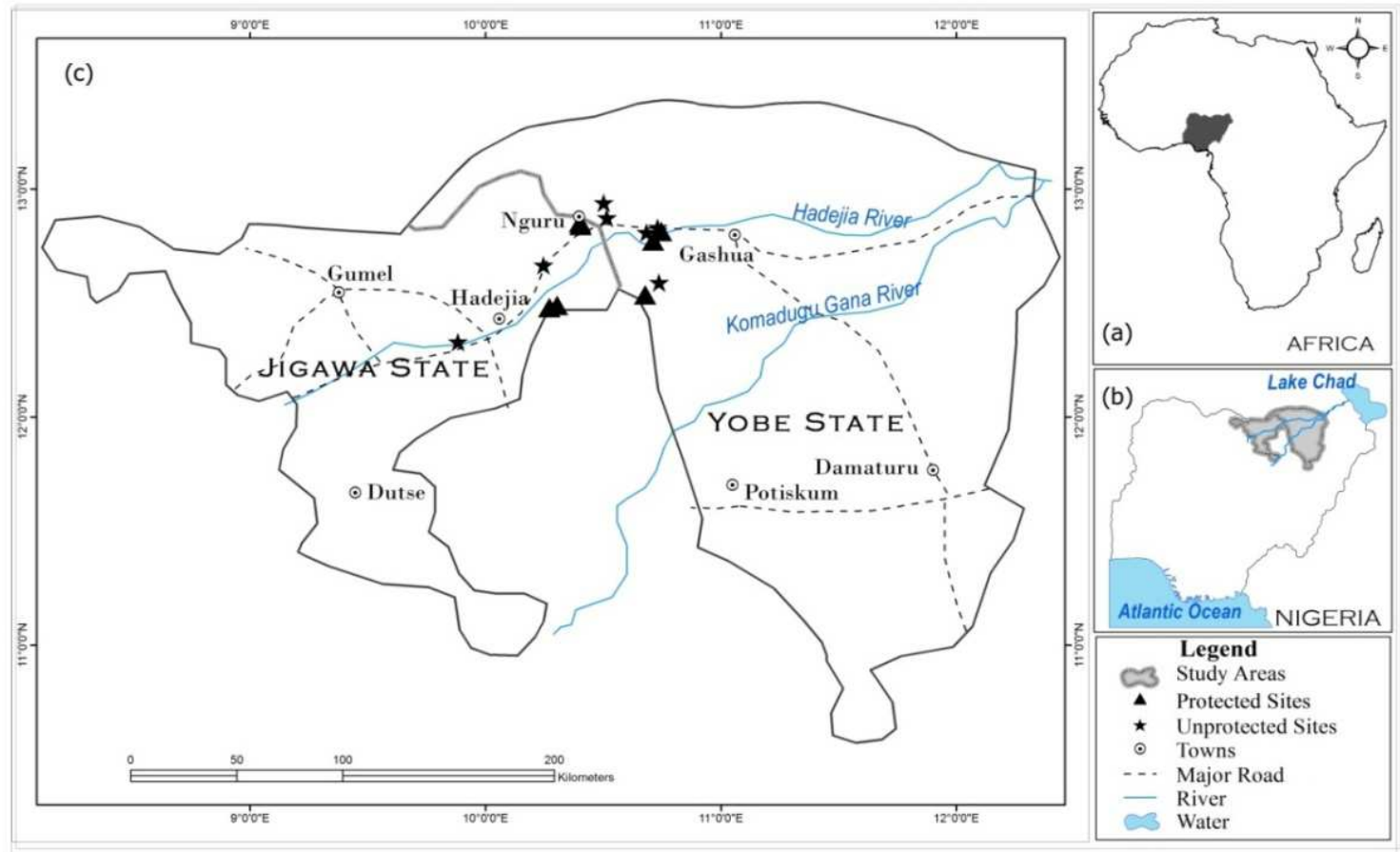

Fig. 1: Location of sampling sites in PAs and UPAs in the HNWs

Table 1: Protected areas in the HNWs

\begin{tabular}{llll}
\hline Protected areas & Designation & Area (ha) & Overlap with IBA (ha) \\
\hline Adiani & Forest Reserve & 132 & 132 \\
Baturiya Wetlands & Game Reserve & 29700 & 29700 \\
Chad Basin & National Park & 230000 & 0 \\
Nguru Lake and & Ramsar site & 58100 & 58100 \\
Marma Channel & & & \\
\hline
\end{tabular}




\section{Bird sampling}

Bird surveys were conducted from October to December, 2015. Seven wetland sites were surveyed in PAs namely Gwayo, Kwasabat, Kandamau, Maram, Marma Channel, Nguru Lake, and Oxbow Lake. Whereas seven wetland sites in the UPAs comprised of Barrack, Dumbari, Hadejia Barrage, Kacallari, Kirikasamma, Muzza, and Zemo. A total of 48 point count stations were surveyed in PAs and 51 in UPAs once per month. Visits were made in the morning from 6:00 to $10: 00 \mathrm{~h}$ and in the evening from 16:00 to 18:00 $\mathrm{h}$ when birds were more active. Each site was surveyed thrice during the study period and the average number of birds counted was taken for all the sites. Point count method described by Bibby (2000) was used to survey bird species. In this technique, during arrival at the point count station, a period of five minutes was observed to allow birds settle down due to any disturbance caused by the observer. Birds seen or heard from a fixed point within a radius of $100 \mathrm{~m}$ using Braun Binoculars $16 \times 10$ $\mathrm{m}$ were observed for 10 minutes in all point counts stations and throughout the study period. Point count stations were spaced $400 \mathrm{~m}$ apart to avoid double counting. Birds were identified using field guide to the birds of Western Africa by Borrow and Demey (2014).

\section{Vegetation sampling}

Vegetation data was collected according to ModifiedWhittaker method by Campbell et al. (2002). This involved three different plot sizes used to sample vegetation. Bigger plots of the size $20 \times 50 \mathrm{~m}$ were established for assessment of trees, within the bigger plot, nested plots of the size $2 \times 5 \mathrm{~m}$ were established for assessing shrubs and herbs and $1 \times 1 \mathrm{~m}$ for grasses, respectively. Name and number of individual trees, herbs and shrubs found within each plot were recorded. Graminae species were recorded on presence- absence basis. Plant species were identified according to Gbile (1984) and Burkill (1995).

\section{Data analysis}

Microsoft Office Software (Excel version 2007) was used to compute the relationship between vegetation diversity/density and bird diversity/density in PAs and UPAs. However, correlation was determined by using scatted plot, while linear correlation in Paleontological Statistical software by Hammer et al. (2001, version 2.17) was used to test if there was significant difference between vegetation diversity/density and bird species diversity/density in PAs and UPAs.

\section{RESULTS}

\section{Bird diversity and density in PAs and UPAs}

A total of 42,255 bird individuals, 148 species, 23 orders and 50 families were recorded from both PAs and UPAs of the HNWs (Appendix I). Families with the highest species were Accipitridae (13 species), Ardeidae (11 species) and Columbidae (9 species), while families with lowest species include Bucerotidae and Jacanidae (2 species each), Coliidae, Coraciidae and Pandionidae (1 species each). Two species in the IUCN Redlist (2015) global conservation concern were also recorded (Birdlife International, 2016b), the Vulnerable European turtle dove Streptopelia turtur and the Near Threatened Pallid harrier Circus macrourus. The former and other 13 species was the first recording in HNWs (Appendix I).

\section{Vegetation composition in PAs and UPAs}

A total of 77 plant species belonging to 34 families were recorded in PAs and UPAs of the HNWs (Appendix II). Forty two species in the PAs and 73 species were recorded in the UPAs, respectively. The following tree species were the most abundant in both areas: Doum Palm Hyphaene thebaica, Egyptian mimosa Acacia nilotica and Paperbark acacia $A$. sieberiana. Dominant shrubs include Camel's foot Piliostigma reticulum, Large jujube Ziziphus abyssinica, and Kharroub Bauhinia rufescens. Dominant herb species in both areas were Marsh barbel Hygrophilus auriculata and Woodrose Ipomoea eriocarpa. Whereas common grasses includes Bermuda grass Cynodon dactylon, Sickle senna Cassia tora and Coffee senna Senna occidentalis. In terms of density, $A$. nilotica and $H$. thebaica registered the highest density in PAs (119.5/ha and 29/ha) while Tamarind Tamarindus indica and Black Plum Vitex doniana registered the lowest density (0.21/ha and $0.1 /$ ha. Similarly in UPAs, $H$. thebaica registered the highest density followed by $A$. nilotica (147.5/ha and 63.38/ha). Krobo christmas tree Hildegardia barteri and Forssk Cadaba farinosa registered the lowest density, $0.12 /$ ha and $0.1 /$ ha (Appendix II).

\section{Relationship between birds and vegetation in PAs and UPAs}

Results showed that neither vegetation diversity nor density correlated with bird diversity nor density in the PAs and UPAs of the HNWs respectively (PAs; $r=$ $0.0370, \quad p>0.05$, UPAs; $r=-0.1720, p>0.05)$. However, despite this, positive associations were observed between certain bird species and plant species. For instance, most dove species including African mourning dove Streptopelia decipiens, Namaqua dove Oena capensis, Vinaceous dove Streptopelia vinacea, and other bird species like Chestnut-bellied starling Lamprotornis pulcher, Crested lark Galerida cristata showed a strong association with bare grassy areas. Some species such as Spur-winged goose, Whitefaced whistling duck Dendrocygna viduata, Garganey Spatula querquedula, African Jacana Actophilornis africanus, Yellow wagtail Motacilla flava, and Squacco heron Ardea rolloides and Knob-billed duck Sarkidiornis melanotos indicated a close relationship with floating and emergent vegetation of Water lilies Nymphae lotus and Hippo grass Vossia cuspidata vegetation. African reed warbler Acrocephalus baeticus, Lesser swamp warbler Acrocepahlus gracilirostris, Village weaver Ploceus cucullatus and Quelea Quelea quelea showed a strong association with emergent vegetation of Southern cattail Typha domingensis especially along the shores in Nguru Lake and Marma channel. Species such as Beautiful sunbird Nectarinia pulchella, Sudan golden sparrow Passer luteus, Red-cheeked cordon-blue Uraeginthus bengalus, and Sedge warbler Acrocephalus schoenobaenus showed a strong positive relation with shrub and tree species especially Acacia spp. 


\section{DISCUSSION}

Bird diversity and density was neither influenced by vegetation diversity nor by vegetation density in both PAs and UPAs. However, other studies (e.g. Henderson and Harper, 1992; Riffel et al., 2001) reported a positive relationship between birds and vegetation. The present study could largely be attributed to low vegetation diversity and density, especially in PAs. A number of studies (e.g. Bideberi, 2013; Connor et al., 2000) related bird diversity and density to complex vegetation structures and wetland factors, such as water levels, wetland size and food. In this case, bird diversity and density in PAs and UPAs of the HNWs possibly depends on other factors, apart from vegetation. Nevertheless, the relationship between birds and certain plant species was observed in both areas. For example, Senegal coucal Centropus senegalensis and African mourning dove showed a strong association with Doum palm vegetation anticipating that it may serve as a nesting and roosting site. In addition, Purple swamphen Porphyrio porphyrio, Common Gallinula chloropus and Lesser moorhen Gallinula angulata as well as Black crake Zapornia flavirostra also showed a positive association with the emergent vegetation of Southern cattail which might serve as foraging ground and shelter. This observation is similar to that of Rajpar and Zakaria (2011) who found bird species such as Common moorhen and Purple swamphen to have strong positive association with emergent vegetation of Typha spp. in Peninsula Malaysia.

The ornithological significance of the HNWs is high and the mosaic habitats are critical for the survival of resident, intra-African and Palearctic migrants and other wildlife as well. The exceptional vegetation of the wetland also benefits the local communities through recharge of drinking water, food crops, protection against erosion and fodder for animals. Thus, should generally be conserved. However, human population is on the increase which may increase demand for the wetland resources, e.g. fuel wood, and farmland areas.

\section{REFERENCES}

Barbier, E. B., Acreman M. \& Knowler D. (1997). Economic evaluation of wetlands. a guide for policy makers and planners. Gland: Ramsar Convention Bureau.

Bibby, C.J. (2000). Bird census techniques. Elsevier, Netherlands. $93-101$.

Bideberi, G. (2013). Diversity, distribution and abundance of avifauna in respect to habitat types: a case study of Kilakala and Bigwa, Morogoro, Tanzania. Masters dissertation submitted to Sokoine University of Agriculture, Tanzania.

BirdLife International (2013). State of Africa's birds: Indicators for our changing world, Cambridge, UK, BirdLife International.

BirdLife International (2016a). Important Bird and Biodiversity Area factsheet: Hadejia-Nguru
Therefore, a good management plan and strict law enforcement especially in PAs will limit exploitation of the wetland resources, minimize conflicts between the different ethnic groups in the wetland and wildlife alike. The possibility of an extension of PAs to include high bird diversity areas (e.g. Dumbari wetland) should be considered. Further studies for birds are recommended in HNWs in the Adiani Forest Reserve and other unexplored wetland areas. This is because many bird species are cryptic and shy which are very hard to detect and in several cases has been recorded only once during month-long surveys (Dinesen, 1998).

Moreover, there is need to increase public awareness (especially the awareness of the indigenous communities in the wetland) on the importance of conserving birds and vegetation, as they play a vital role in the ecosystem. The management of the wetland needs to step up efforts to protect certain vegetation types (e.g. Acacia spp.) against overexploitation. This is because they are important roosting sites for the vulnerable European turtle dove. Finally, the study has demonstrated that both PAs and UPAs of the HNWs are important for bird conservation. Thus, legal attention will be of uttermost importance for the long-term conservation of the wetland rich bird species, which from conservation point of view is very important.

\section{Acknowledgements}

The Nigerian Conservation Foundation, Chad Basin National Park (Dagona Waterfowl Sanctuary) and Jigawa State Ministry of Environment kindly permitted us to work in the wetlands. They provided excellent housing and other facilities, Mr. Harry Hanson, Mr. Baba Hamisu, Mr. Ibrahim Dala, Mr. Musa Likori and Mr. Muhammad Bala helped enormously in the field.

\section{Contribution of authors}

A. S. Ringim collected the field data, analyzed the data and wrote the manuscript, while M. M. Dogara proofread and reviewed the manuscript.

\section{Conflict of interest}

The authors declare no conflict of interest.

wetlands. http://www.birdlife.org (Accessed 11/10/2016).

BirdLife International (2016b). IUCN Redlist for birds. http://www.birdlife.org (Accessed 19/02/2016).

Beese, W. J. \& Bryant, A. A. (1999). Effect of alternative silvicultural systems on vegetation and bird communities in coastal montane forests of British Columbia, Canada. Forest Ecology and Management, 115(2), 231-242.

Borrow, N. \& Demey, R. (2014). Field Guide to the Birds of Western Africa. Princeton University Press, United States.

Burkill, H. M. (1995). The useful plants of west tropical Africa, Vols. 1-3 (No. 2. Ed.). Royal Botanic Gardens, Kew. 
Campbell, P., Comiskey, J., Alonso, A., Dallmeier, F., Nunez, P., Beltran, H. \& Udvardy, S. (2002). Modified Whittaker plots as an assessment and monitoring tool for vegetation in a lowland tropical rainforest. Environmental Monitoring and Assessment, 76(1), 19-41.

Connor, E. F., Courtney, A. C. \& Yoder, J. M. (2000). Individuals-area relationships: the relationship between animal population density and area. Ecology, 81(3), 734-748.

Dinesen, L. (1998). Priorities for biodiversity conservation in the Udzungwa Mountains, Tanzania-based on bird data. Journal of East African Natural History, 87(1), 195-204.

Ezealor, A. U. \& Giles, R. H. (1997). Wintering Ruffs Philomachus pugnax are not pest of Rice Oryza spp. in Nigeria's Sahelian Wetlands. Wildfowl, 48(48), 202-209.

Gbile, Z. O. (1984). Vernacular names of Nigerian Plants. Forestry Research Institute of Nigeria, Ibadan, Nigeria.

Hammer, Ø., Harper, D. A. T. \& Ryan, P. D. (2001). PAST: Paleontological statistics software package for education and data analysis. Palaeontologia Electronica, 1: 9.

Hawkins, B. A., Diniz-Filho J. A. F., Jaramillo C. A. \& Soeller, S. A. (2007). Climate niche conservation, and the global bird diversity gradient. The American Naturalist, 170(S2), 16-24.

Henderson, I.G. and Harper, D.M. (1992). Bird distribution and habitat structure on Lake Naivasha, Kenya. African Journal of Ecology, 30(3), 223-232.

Hurlbert, A. H. (2004). Species-energy relationships and habitat complexity in bird communities. Ecology Letters, 7(8), 714-720.
Lameed, F. (2011). Species diversity and abundance of wild birds in Dagona-Waterfowl Sanctuary Borno State, Nigeria. African Journal of Environmental Science and Technology, 5(10), 855- 866.

Kumar, P. \& Gupta, S. K. (2009). Diversity and abundance of wetland birds around Kurukshetra, India. Our Nature, 7(1), 212-217.

Mironga, J. M. (2006). Degradation of wetland ecosystems: A case study of Kisii District, western Kenya. Biodiversity, 7(3-4), 3-16.

Neave, H. M., Cunningham, R. B., Norton, T. W. \& Nix, H. A. (1996). Biological inventory for conservation evaluation III. Relationships between birds, vegetation and environmental attributes in Southern Australia. Forest Ecology and Management, 85(1), 197-218.

Rajpar, M. N. \& Zakaria, M. (2011). Bird species abundance and their correlationship with microclimate and habitat variables at Natural Wetland Reserve, Peninsular Malaysia. International Journal of Zoology, 217. doi: $10.1155 / 2011 / 758573$

Riffel, S. K., Keas, B. E. \& Burton, T. M. (2001). Area and habitat relationships of birds in Great Lakes coastal wet meadows. Wetlands, 21(4), 492-507.

Sulaiman, I. M., Cresswell, W. \& Dami, F. D. (2014). Bird diversity and abundance in relation to Typha occurrence at the Hadejia- Nguru wetlands, Nigeria. Biotropic Research International Journal, 6(1), 1-5.

Sulaiman, I. M, Abubakar, M. M., Ringim, A. S., Apeverga, P. T., \& Dikwa, M. A. (2015). Effects of wetlands type and size on bird diversity and abundance at the Hadejia- Nguru Wetlands, Nigeria. International Journal of Research Studies in Zoology, 1(1), 15-21. 
Bajopas Volume 10 Number 2 December, 2017

Appendix I: Checklist of bird species in PAs and UPAs of the HNWs recorded during the study period (October to December, 2015). New records added to the existing literature $(*)$.

\begin{tabular}{|c|c|c|}
\hline Family & Common names & Species name \\
\hline \multirow[t]{6}{*}{ Anatidae } & African Pygmy Goose & Nettapus auritus \\
\hline & Fulvous Whistling Duck & Dendrocygna bicolor \\
\hline & Garganey & Spatula querquedula \\
\hline & Knob-billed Duck & Sarkidiornis melanotos \\
\hline & Spur-winged Goose & Plectropterus gambensis \\
\hline & White-faced Whistling Duck & Dendrocygna viduata \\
\hline \multirow[t]{3}{*}{ Apodidae } & African Palm Swift & Cypsiurus parvus \\
\hline & Common Swift & Apus apus \\
\hline & Little Swift & Apus affinis \\
\hline \multirow[t]{2}{*}{ Bucerotidae } & African Grey Hornbill & Lopoceros nasutus \\
\hline & Northern Red-billed Hornbill & Tockus erythrorhynchus \\
\hline \multirow[t]{13}{*}{ Accipitridae } & African Harrier Hawk & Polyboroides typus \\
\hline & African Swallow-tailed Kite & Chelictinia riocourii* \\
\hline & Black Shouldered Kite & Elanus axillaris \\
\hline & Black kite & Milvus migrans \\
\hline & Dark Chanting Goshawk & Melierax metabates \\
\hline & Gabar Goshawk & Micronisus gabar \\
\hline & Grasshopper Buzzard & Butastur rufipennis \\
\hline & Lizard Buzzard & Kaupifalco monogrammicus \\
\hline & Montagu's Harrier & Circus pygargus \\
\hline & Pallid Harrier & Circus macrourus \\
\hline & Shikra & Accipeter badius \\
\hline & Western Marsh Harrier & Circus aeruginosus \\
\hline & Yellow-billed Kite & Milvus migrans parasitus \\
\hline \multirow[t]{3}{*}{ Ciconiidae } & Abdim's Stork & Ciconia abdimii \\
\hline & African Openbill Stork & Anastomus lamelligerus \\
\hline & White Stork & Ciconia ciconia \\
\hline \multirow[t]{2}{*}{ Cuculidae } & Great Spotted Cuckoo & Clamator glandarius \\
\hline & Senegal Coucal & Centropus senegalensis \\
\hline Coliidae & Blue-naped Mousebird & Urocolius macrourus \\
\hline \multirow[t]{4}{*}{ Alcedinidae } & African Pygmy Kingfisher & Ispidina picta \\
\hline & Grey-headed Kingfisher & Halcyon leucocephala \\
\hline & Malachite Kingfisher & Corythornis cristatus \\
\hline & Pied Kingfisher & Ceryle rudis \\
\hline \multirow[t]{9}{*}{ Columbidae } & African Mourning Dove & Streptopelia decipiens \\
\hline & Black-billed Wood Dove & Turtur abyssinicus \\
\hline & Blue-spotted Wood Dove & Turtur afer \\
\hline & European Turtle Dove & Streptopelia turtur* \\
\hline & Laughing Dove & Streptopelia senegalensis \\
\hline & Namaqua Dove & Oena capensis \\
\hline & Speckled Pigeon & Columba guinea \\
\hline & Tambourine Dove & Turtur tympanistria* \\
\hline & Vinaceous Dove & Streptopelia vinacea \\
\hline Coraciidae & Abyssinian Roller & Coracias abyssinicus \\
\hline \multirow[t]{2}{*}{ Charadriidae } & Black-headed Lapwing & Vanellus tectus \\
\hline & Spur-winged Lapwing & Vanellus spinosus \\
\hline \multirow[t]{2}{*}{ Jacanidae } & African Jacana & Actophilornis africanus \\
\hline & Lesser Jacana & Microparra capensis \\
\hline \multirow[t]{3}{*}{ Laridae } & Gull-billed Tern & Gelochelidon nilotica* \\
\hline & Grey-headed Gull & Larus cirrocephalus* \\
\hline & Whiskered Tern & Chilidonias hybrida \\
\hline \multirow[t]{6}{*}{ Scolopacidae } & Common Sandpiper & Actitis hypoleucos \\
\hline & Common Snipe & Gallinago gallinago \\
\hline & Green Sandpiper & Tringa ochropus \\
\hline & Little Stint & Calidris minuta \\
\hline & Ruff & Calidris pugnax \\
\hline & Spotted Redshank & Tringa erythropus \\
\hline
\end{tabular}


Bajopas Volume 10 Number 2 December, 2017

Recurvirostridae
Falconidae
Numididae
Odontophoridae
Rallidae

Musophagidae Lybiidae

Ardeidae

Threskiornithidae Psittacidae

Pteroclidae Caprimulgidae Upupidae Phaoeniculidae Alaudidae Cisticolidae

Corvidae

Estrildidae

Fringillidae Hirundinidae

Laniidae

Malaconotidae

Meropidae

Motacillidae Muscicapidae
Wood Sandpiper

Black-winged Stilt

Grey Kestrel

Lanner Falcon

Red-necked Falcon

Helmeted Guineafowl

Stone Patridge

Allen's Gallinule

Black Crake

Common Moorhen

Lesser Moorhen

Purple Swamphen

Western Grey Plantain-eater

Bearded Barbet

Vieillot's Barbet

Yellow-fronted Tinkerbird

Black Heron

Black-headed Heron

Cattle Egret

Great Egret

Green-backed Heron

Grey Heron

Intermediate Egret

Little Bittern

Little Egret

Purple Heron

Squacco Heron

Glossy Ibis

Red-headed Lovebird

Rose-ringed Parakeet

Senegal Parrot

Four-banded Sandgrouse

Standard-winged Nightjar Hoopoe

Green Wood-hoopoe

Crested Lark

Grey-backed Camaroptera

Tawny-flanked Prinia

Winding Cisticola

Zitting Cisticola

Piapiac

Pied Crow

Cut-throat Finch

Green-winged Pytilia

Red-billed Firefinch

Red-cheeked Cordon Blue

Yellow-fronted Canary

Common Sand Martin

Ethiopian Swallow

Plain Martin

West African Swallow

Southern Grey Shrike

Woodchat Shrike

Yellow-billed Shrike

Black-crowned Tchagra

Yellow-crowned Gonolek

Little Bee-eater

Little Green Bee-eater

Yellow Wagtail

Black Scrub Robin

Northern Wheatear
Tringa glareola

Himantopus himantopus

Falco ardosiaceus

Falco biarmicus

Falco ruficollis

Numida meleagris*

Ptilopachus petrosus

Porphyrio alleni

Zapornia flavirostra

Gallinula chloropus

Gallinula angulata

Porphyrio porphyrio

Crinifer piscator

Pogoniulus dubius

Lybius vieilloti

Pogoniulus chrysoconus

Egretta ardesiaca

Ardea melanocephala

Bubulcus ibis

Ardea alba

Butorides striata

Ardea cinerea

Ardea intermedia

Ixobrychus minutus

Egretta garzetta

Aredea purperea

Ardea rolloides

Plegadis falcinellus

Agapornis pullarius*

Psittacula krameri

Poicephalus senegalus

Pterocles quadricinctus

Caprimulgus longipennis*

Upupa epops

Phoeniculus purpureus

Galerida cristata

Camaroptera brachyura

Prinia subflava

Cisticola juncidis

Cisticola fasciata

Ptilostomus afer

Corvus albus

Amadina fasciata

Pytilia melba*

Lagonosticta senegala

Uraeginthus bengalus

Serinus mozambicus

Riparia riparia

Hirundo aethiopica

Riparia paludicola

Ceropis domicella

Lanius meridionalis

Lanius senator*

Corvinella corvina

Tchagra senegalus

Laniarius barbarus

Merops pusillus

Merops orientalis

Motacilla flava

Cercotrichas podobe

Oenanthe oenanthe* 
Bajopas Volume 10 Number 2 December, 2017

\begin{tabular}{lll}
\hline Nectariniidae & Beautiful Sunbird & Nectarinia pulchella \\
Pandionidae & Osprey & Pandion halieatus \\
Passeridae & Northern Grey-headed Sparrow & Passer griseus \\
& Sudan Golden Sparrow & Passer luteus \\
Phalacrocoracidae & Speckle-fronted Weaver & Sporopipes frontalis \\
Phasianidae & Long-tailed Cormorant & Microcarbus africanus \\
Ploceidae & Double-spurred Francolin & Pternistis petrosus \\
& Black-headed Weaver & Ploceus melanocephalus \\
& Little Weaver & Ploceus luteolus \\
& Northern Red Bishop & Euplectes franciscanus \\
& Red-billed Quelea & Quelea quelea \\
& Village Weaver & Ploceus cucullatus \\
Vycnonotidae & Vitellin Masked Weaver & Ploceus intermedius \\
Sturnidae & White-billed Buffalo Weaver & Bubalornis albirostris \\
& Yellow-crowned Bishop & Euplectes afer \\
& Common Bulbul & Pycnonotus barbatus \\
Sylviidae & Chestnut-bellied Starling & Lamprotornis pulcher \\
& Great Blue-eared Starling & Lamprotornis chalybaeus \\
& Long-tailed Glossy Starling & Lamprotornis caudatus \\
& Yellow-billed Oxpecker & Buphagus africanus \\
& African Reed Warbler & Acrocephalus baeticus* \\
& Common Whitethroat & Sy/via communis* \\
& European Reed Warbler & Acrocephalus scirpaceus* \\
Giduidae & Greater Swamp Warbler & Acrocepahlus rufescens \\
& Lesser Swamp Warbler & Acrocepahlus gracilirostris \\
Northern Crombec & Sy/vietta brachyura \\
& Sedge Warbler & Acrocephalus schoenobaenus \\
& Brown Babbler & Turdoides plebejus \\
& Sahel Paradise Whydah & Vidua orientalis \\
Village Indigobird & Vidua chalybaeta \\
\hline
\end{tabular}


Bajopas Volume 10 Number 2 December, 2017

Appendix II: Vegetation composition in PAs and UPAs of the HNWs recorded during the study period (October to December, 2015). Key: Presence (+), Absence (), D/ha (Density/ha)

\begin{tabular}{|c|c|c|c|c|c|c|c|}
\hline \multirow[b]{2}{*}{ Family } & \multirow[b]{2}{*}{ Species name } & \multirow[b]{2}{*}{ Common names } & \multirow[b]{2}{*}{ Habit } & \multicolumn{2}{|c|}{ PAs } & \multicolumn{2}{|c|}{ UPAs } \\
\hline & & & & Individual & D/ha & Individual & D/ha \\
\hline Amaranthaceae & Achyranthes aspera L. & Chaff flower & Graminae & + & + & - & - \\
\hline Araceae & Pistia stratiotes $\mathrm{L}$. & Water lettuce & Graminae & + & + & - & - \\
\hline Asclepiadaceae & Leptadenia hastata (Pers.) Decne. & Leptadenia & Graminae & + & + & + & - \\
\hline Asteraceae & Ambrosia maritima $\mathrm{L}$. & Wild indigo & Graminae & + & + & + & + \\
\hline Asteraceae & Acanthospermum hispidum DC. & Bristly starbur & Graminae & - & - & + & + \\
\hline Convulvulaceae & Evolvulus decumbens $\mathrm{R}$. Br. & Dwarf morning glory & Graminae & - & - & + & + \\
\hline Cucurbitaceae & Ipomoea asarifolia Roem. \& Schult & Morning glory & Graminae & + & + & + & + \\
\hline Cucurbitaceae & Lagenaria siceraria (Molina) Standl. & Bottle gourd & Graminae & - & - & + & + \\
\hline Cyperaceae & Cyperus esculentus $\mathrm{L}$. & Nut grass & Graminae & - & - & + & + \\
\hline Cyperaceae & Cyperus rotundus $\mathrm{L}$. & Coco grass & Graminae & + & + & + & + \\
\hline Leguminosae & Cassia singueana Delile & Cassia & Graminae & - & - & + & + \\
\hline Leguminosae & Diadilium guineense Willd. & Velvet tamarind & Graminae & - & - & + & + \\
\hline Leguminosae & Senna italica Mill. & Italian senna & Graminae & + & + & + & + \\
\hline Leguminosae & Senna occidentalis (L.) Link & Coffee senna & Graminae & - & - & + & + \\
\hline Leguminosae & Sesbania dalzielli E. Phillips \& Hutch. & Riverhemp & Graminae & - & - & + & + \\
\hline Malvaceae & Gossypium hirsutum L. & Mexican cotton & Graminae & - & - & + & + \\
\hline Nyctaginaceae & Boerhavia diffusa L. & Hogweed & Graminae & - & - & + & + \\
\hline Nymphaeaceae & Nymphae lotus $\mathrm{L}$. & Water lily & Graminae & + & + & + & + \\
\hline Poaceae & Acroceras amplectens Stapf. & Acroceras & Graminae & - & - & + & + \\
\hline Poaceae & Andropogon gayanus Kunth & Gamba grass & Graminae & + & + & + & + \\
\hline Poaceae & Cenchrus biflorus Roxb. & Indian sandbur & Graminae & - & - & + & + \\
\hline Poaceae & Cynodon dactylon (L.) Pers. & Bermuda grass & Graminae & + & + & + & + \\
\hline Poaceae & Digitaria debilis Willd. & Finger grass & Graminae & + & + & + & + \\
\hline Poaceae & Eragrostis tremula Hochst. ex Steud. & Canegrass & Graminae & - & - & + & + \\
\hline Poaceae & Heteropogon contortus (L.) Beauv. ex Roemer \& J.A. Schultes & Steakgras & Graminae & - & - & + & + \\
\hline Poaceae & Pennisetum pedicellatum Trin. & Annual Kyasuwa grass & Graminae & + & + & + & + \\
\hline Poaceae & Phragmites australis (Cav.) Steud. & Common reed & Graminae & + & + & + & + \\
\hline Poaceae & Schizachyrium exile (Hochst.) Pilg. & Bluestems/Pilger & Graminae & - & - & + & + \\
\hline Poaceae & Urelytrum giganteum Pilg. & Pilger & Graminae & - & - & + & + \\
\hline Poaceae & Vossia cuspidata Griff. & lHippo grass & Graminae & + & + & + & + \\
\hline Tiliaceae & Corchorus tridens $\mathrm{L}$. & Wild jute & Graminae & - & - & + & + \\
\hline Typhaceae & Typha domingensis Pers. & Southern cattail & Graminae & + & + & + & + \\
\hline Lamiaceae & Clerodendrum capitatum Hook. & Cleredenron & Graminae & - & - & + & + \\
\hline Acanthaceae & Calophanes perrottetii Nees. & Snake herb & Herb & + & + & - & - \\
\hline Acanthaceae & Hygrophila auriculata (Schumach.) & Marsh barbel & Herb & 7 & 0.97 & 2 & 0.28 \\
\hline Commelinaceae & Commelina erecta Chapm. & Slender dayflower & Herb & - & - & 6 & 0.62 \\
\hline Convulvulaceae & Ipomoea eriocarpa $\mathrm{R}$. Br. & Woodrose & Herb & - & - & 7 & 0.73 \\
\hline Cucurbitaceae & Momordica balsamina L. & African pumpkin & Herb & 2 & 0.28 & 3 & 0.31 \\
\hline Euphorbiaceae & Ricinus communis $\mathrm{L}$. & Castorbean & Herb & - & - & 7 & 0.73 \\
\hline Leguminosae & Crotalaria mucronata Desv. & Rattlepod & Herb & - & - & 16 & 1.6 \\
\hline
\end{tabular}




\begin{tabular}{|c|c|c|c|c|c|c|c|}
\hline Lamiaceae & Leonotis nepetifolia Schimp. ex Benth. & Wild tea bush & Herb & - & - & 4 & 0.42 \\
\hline Malvaceae & Hibiscus sabdariffa L. & Roselle & Herb & - & - & 2 & 0.28 \\
\hline Annonaceae & Annona senegalensis Pers. & African custard-apple & Shrub & - & - & 12 & 0.2 \\
\hline Asclepiadaceae & Calotropis procera (Aiton) W.T.Aiton & Kapok & Shrub & 27 & 3.03 & 171 & 17.85 \\
\hline Capparaceae & Cadaba farinosa Fossk. & Forssk & Shrub & - & - & 1 & 0.1 \\
\hline Combretaceae & Guiera senegalensis J.F.Gmel. & Moshi medicine & Shrub & 3 & 0.31 & 5 & 0.58 \\
\hline $\begin{array}{l}\text { Leguminosae } \\
\text { Leguminosae }\end{array}$ & $\begin{array}{l}\text { Bauhinia rufescens Lam } \\
\text { Piliostigma thonningii (Schumach.) Milne-Redh. }\end{array}$ & $\begin{array}{l}\text { Kharroub } \\
\text { Camel's foot }\end{array}$ & $\begin{array}{l}\text { Shrub } \\
\text { Shrub }\end{array}$ & $\begin{array}{c}52 \\
133\end{array}$ & $\begin{array}{c}5.9 \\
15\end{array}$ & $\begin{array}{l}107 \\
192\end{array}$ & $\begin{array}{l}25.25 \\
21.88\end{array}$ \\
\hline Rhamnaceae & Ziziphus abyssinica Hochst. ex A. Rich. & Large jujube & Shrub & 32 & 4.12 & 75 & 8.12 \\
\hline Rubiaceae & Mitragyna inermis (Willd.) \& Kuntze & Abura & Shrub & 13 & 0.56 & 7 & 0.82 \\
\hline Salvadoraceae & Salvadora persica L. & Mustard bush & Shrub & - & - & 2 & 0.21 \\
\hline Lamiaceae & Vitex doniana Sweet & African oak & Tree & 1 & 0.1 & 1 & 0.1 \\
\hline Anacardiaceae & Mangifera indica $\mathrm{L}$. & Mango & Tree & 2 & 0.24 & 13 & 1.39 \\
\hline Arecaceae & Cocos nucifera L. & Palm tree & Tree & 8 & 0.88 & - & - \\
\hline Arecaceae & Hyphaene thebaica (L.) Mart & Doum palm & Tree & 267 & 29 & 1282 & 147.5 \\
\hline Arecaceae & Phoenix dactylifera L. & Date palm & Tree & 6 & 0.73 & 6 & 0.62 \\
\hline Ebenaceae & Diospyros sabiensis Hiern & African Ebony & Tree & 8 & 1.01 & 5 & 0.64 \\
\hline Leguminosae & Acacia nilotica (L.) Delile & Egyptian mimosa & Tree & 901 & 119.5 & 505 & 63.38 \\
\hline Leguminosae & Acacia Senega/Willd. & Gum Arabic & Tree & 7 & 0.97 & 20 & 2.37 \\
\hline Leguminosae & Acacia seya/Delile & Shittah tree & Tree & 3 & 0.42 & 109 & 14.48 \\
\hline Leguminosae & Acacia sieberiana (DC.) Kyal. \& Boatwr & Paperbark acacia & Tree & 173 & 23.6 & 176 & 21.4 \\
\hline Leguminosae & Faidherbia albida (Delile) A. Chev. & Apple ring-acacia & Tree & 44 & 4.9 & 45 & 4.89 \\
\hline Leguminosae & Mimosa asperata L. & Giant sensitive tree & Tree & 43 & 5.97 & 3 & 0.31 \\
\hline Leguminosae & Tamarindus indica L. & Tamarind & Tree & 2 & 0.2 & 7 & 0.9 \\
\hline Bombacaceae & Adansonia digitata $\mathrm{L}$. & African Baobab & Tree & - & - & 13 & 1.25 \\
\hline Sterculiaceae & Hildegardia barteri (Mast.) Kosterm. & Krobo Christmas tree & Tree & 3 & 0.31 & 1 & 0.12 \\
\hline Meliaceae & Azadirachta indica A. Juss & Neem tree & Tree & 60 & 6.5 & 275 & 29.16 \\
\hline Moraceae & Ficus thonningii Blume & Wild fig & Tree & 3 & 0.31 & 5 & 0.5 \\
\hline Moringaceae & Moringa oleifera Lam & Moringa & Tree & - & - & 2 & 0.21 \\
\hline Rhamnaceae & Ziziphus mucronata Willd. & Buffalo thorn & Tree & 3 & 0.42 & 29 & 3.32 \\
\hline Balanitaceae & Balanites aegyptiaca Delile & Desert date & Tree & 28 & 2.92 & 42 & 5.56 \\
\hline
\end{tabular}

